\title{
Thyroid Disorders and Bone Mineral Homeostasis
}

\author{
Eva Feigerlova, Marc Klein, Anna Angelousi, Lelia Groza, Bruno Leheup and \\ Georges Weryha
}

Additional information is available at the end of the chapter

http://dx.doi.org/10.5772/46207

\section{Introduction}

Thyroid hormones play a crucial role in the skeletal growth, peak bone mass acquisition and maintenance of bone mass. Abnormalities in hypothalamic-pituitary-thyroid axis in infancy and childhood have been shown to interfere with a normal linear growth and skeletal maturation. Hypothyroidism compromises normal bone formation and results in slowing of linear growth. Thyrotoxicosis leads to growth acceleration, diminution of bone mass and advance in bone age. Studies in animal models have demonstrated the importance of thyroid hormone signaling in the maintenance of bone mass in adulthood. Increased risk of fracture has been demonstrated in both hypothyroidism and hyperthyroidism. The thyroid hormone, 3,5,3'-triiodothyronine (T3), has long been considered to play a primordial role in the skeletal homeostasis. However, recent studies have shown that TSH acts as a direct regulator of bone remodeling, highlighting the importance of integrity of the hypothalamopituitary-thyroid axis.

This chapter will review our current understanding regarding the action of thyroid hormones on the bone development and maintenance of bone mass, under normal conditions and as a result of thyroid gland dysfunction. Mechanism of thyroid hormone action will be illustrated in relation to bone with the focus on the genetic regulation and the molecular interactions between thyroid hormones and skeletal cells. Clinical consequences of thyroid dysfunction on the growth and skeletal maturation will be detailed. We will review the published literature regarding BMD in hyperthyroid and hypothyroid patients including patients on medical therapy, as well as the influence of sex and menopause on the maintenance of bone mass. The impact of treatments for thyroid dysfunction on the bone mineral metabolism will be discussed. 


\section{Role of thyroid hormones in bone growth and metabolism}

Thyroid hormones are critical for the skeletal development and the bone maintenance. The thyroid hormone, 3,5,3'-triiodothyronine (T3), is responsible for major actions of thyroid hormones. T3 binds to nuclear receptors that regulate gene transcription via interaction with thyroid hormone response elements of specific genes (Sap et al., 1986; Weinberger et al., 1986; Thompson et al., 1987). Recently, non-genomic actions of T3 and T4 have been described (Cheng et al., 2010). Local tissue availability of T3 seems to be regulated by type 2 and 3 deiodinase (St Germain et al, 2009). The nuclear thyroid hormone receptors (TRs) are derived from the THRA and THRB genes coding for the TR $\alpha 1$ and $\beta 1-2$ T3-binding isoforms, truncated isoforms $\Delta \alpha 1, \Delta \alpha 2$ and $\Delta \beta 3$, and a TRa2 non-T3-binding isoform of unknown function (Lazar et Chin et al, 1990; Lazar, 1993; Chassande et al, 1997; Williams, 2000; Cheng et al, 2010). Expression of TR $\alpha 1$ and TR $\beta 1$ was described in growth plate chondrocytes, osteoblasts, and stromal cells of bone marrow (Williams et al, 1994; Abu et al, 1997; Ballock et al, 1999; Bradley et al, 1992; Bassett et Williams, 2003; Siddiqi et al, 2002). Expression of TR $\alpha$ in the skeleton is higher than that of TR $\beta$ (Bookout et al, 2006; O'Shea et al, 2003).

\subsection{Thyroid hormone and bone development}

Studies on animal models have brought valuable insights into role of TRs in bone development and growth. Mice lacking TR $\beta$ or TR $\alpha 1$ did not display abnormalities in skeletal development (Forrest et al, 1996; Wikstrom et al, 1998). On the other hand, genetic disruption of both receptors (TR $\alpha 1$ and TR $\beta$ ) led to delayed ossification and disorders in development of epiphyseal growth plates (EGPs; Gothe et al, 1999). Pax-8 $8^{-/-}$mice, expressing all TR isoforms, but lacking the follicular cells producing T4 and T3 in the thyroid gland, displayed more severe abnormalities in bone development than mice KO for all TRs (TR $\alpha^{0 / 0}$, TR $\beta^{--}$) (Flamant et al, 2002). The authors concluded that the unliganded TRs (aporeceptors) on thyroid hormone responsive genes have repressor effects during bone development. In support of this, $\mathrm{Pax}-8^{---\mathrm{TR}} \alpha^{0 / 0}$, but not Pax- $8^{--\mathrm{TR}} \beta^{---}$, compound mutants presented a partial rescue of the bone phenotype (O'Shea et Williams, 2002; Flamant et al, 2002). Another study was realized employing mice invalidated for TR $\alpha$. These animals were euthyroid, but displayed a growth delay with abnormal bone development and ossification (Bassett et al 2007a, 2007b; Gauthier et al, 1999, 2001; O'Shea 2003, 2005). Mice lacking all TR $\alpha$ isoforms presented a less severe impairment of bone development than TR $\alpha$-/- mice, pointing to the role of non-T3 binding TR $\alpha$ isoforms ( $\Delta \alpha 1$ and $\Delta \alpha 2$ ) (Gauthier et al, 2001). On the other hand, mice with nonfunctional TR $\beta$ displayed augmentation in circulating thyroid hormone levels associated with dysregulation of hypothalamo-pituitary-thyroid axis. These animals had skeletal signs of hyperthyroidism, increased bone mineral deposition and acceleration of growth-plate maturation, resulting in a short adult body size (Bassett et al, 2007a; O'Shea et al, 2003). These findings suggested an increased skeletal response to T3 via TR $\alpha$, which was consistent with the hypothesis that elevated circulating thyroid hormone levels in TR $\beta$ mutant mice result in an increased skeletal response to T3 via TR $\alpha$ (O'Shea et al, 2006). Recently, GC-1, thyroid hormone analogue targeting preferentially TR $\beta 1$ over TR $\alpha 1$, has 
partially reverted skeletal development and maturation defects in hypothyroid rats (Freitas et al, 2005). This finding is suggestive of TR $\beta 1$ involvement in bone growth.

Thyroid hormones regulate bone development also indirectly through the growth hormone (GH) and insulin-like growth factor-I (IGF-I) axis. Previously, it was demonstrated that T4 enhanced the growth promoting effect of GH/IGF-I (Thorngren et Hansson, 1974) and could stimulate longitudinal bone growth in hypophysectomized rats (Thorngren et Hansson, 1973; Ray et al, 1954). T3 was shown to interact with the thyroid hormone receptor - thyroid hormone responsive element complex (TR-TRE) in the GH promoter to regulate GH gene transcription (Glass et al, 1987; Koenig et al, 1987). However, GH without T3 did not promote the maturation (Ballock et Reddi, 1994) and organization (Lewinson et al, 1989) of growth plate chondrocytes and GH replacement could not rescue the impaired ossification in TR $\alpha$ and TR $\beta$-null mice (Kindblom et al, 2001). In TR $\alpha 1^{-1-} \beta^{-/-}$mice, GH substitution reversed the growth phenotype, but not the defective ossification (Kindblom et al, 2001). On the other hand, inactivation of GH or IGF-I receptors in mice was associated with delayed ossification (Liu et al, 1993; Sjogren et al, 2000).

Overall, the literature data indicate importance of both TRs and GH-IGF-I axis in skeletal development. Other factors, such as the Indian Hedgehog (Ihh), parathyroid hormonerelated peptide (PTHrP), fibroblast growth factor receptor and Wnt- $\beta$-catenin signaling pathways, are implicated in this process (Barnard et al, 2005; O'Shea et al, 2005; Stevens et al, 2000, 2003; Wang et al, 2007). Further studies are warranted to clarify the exact mechanisms underlying the physiological regulation of bone development.

\subsection{Thyroid hormone and bone remodeling}

Literature evidence points to the critical importance of thyroid hormones in bone remodeling and maintenance. Adult euthyroid mice invalidated for TR $\alpha$ have reduced osteoclastic bone resorption and increased trabecular bone volume and mineralization (Bassett et al, 2007a, 2007b), indicating a critical role of TR $\alpha$ in T3 action in bone cells. On the other hand, increased osteoclastic bone resorption and severe osteoporosis were demonstrated in adult TR $\beta$ mutant mice, suggestive of thyroid hormone excess in TR $\alpha$ expressing skeletal cells (Bassett et al, 2007a, 2007b; Gauthier et al, 2001; O'Shea et al, 2006).

The bone architecture and strength are maintained by a balanced process of remodeling, which involves recruitment of osteoclast and osteoblasts. T3 can induce differentiation and inhibits proliferation of osteoblastic cells. T3 was shown to promote production of IL-6, IL-8, IGF-I and its binding proteins IGFBP2-4 in bone marrow stromal cells and osteoblasts (Milne et al, 2001; Siddiqi et al, 1998), and to increase the expression of several bone-related genes, including osteocalcin, collagen type I, gelatinase B and collagenase 3 (Gouveia et al 2001; Milne et al 1998; Pereira 1999; Varga et al 1997; Williams et al 1994). T3 is implicated in chondrogenesis, angiogenesis, bone matrix formation and mineralization (Himeno et al, 2002; Makihira et al, 2003; Pereira et al, 1999). In primary cultures of growth plate chondrocytes, T3 inhibits chondrocyte clonal expansion and cell proliferation, induces hypertrophic chondrocyte differentiation and promotes cartilage matrix mineralization (Robson et al, 2000). 
Furthermore, T3 is involved in local signaling pathways by stimulating osteoblast responses to IGF1-I, PTH and fibroblast growth factors. T3 is a critical regulator of the Ihh - bone morphogenetic protein (BMP) - PTHrP feedback loop (Stevens et al, 2000). Hypothyroidism is marked by increased PTHrP expression and impaired hypertrophic chondrocyte differentiation (Stevens et al, 2000). In hyperthyroidism, reduced expression of PTHrP associated with augmentation of BMP enhances hypertrophic chondrocyte differentiation (Lassova et al, 2009; Stevens et al, 2000). It has also been shown that T3 regulates terminal differentiation of growth plate chondrocytes in part through controlling cell cycle progression at the G1/S restriction point (Ballock et al, 2000). T3 mediates osteoclastic bone resorption through activation of osteoblasts, which then release receptor activator for NF- $\kappa \mathrm{B}$ ligand (RANKL), a member of the TNF cytokine family. RANKL is a ligand for osteoprotegerin, a cytokine that regulates osteoclastic differentiation, and functions as a key factor for osteoclast differentiation and activation by inhibiting osteoclasts apoptosis (Allain et al, 1992; Britto et al, 1994).

Overall, T3 seems to enhance activity of osteoblasts by various mechanisms and signaling loops. Although the effects of thyrotoxicosis in adult bone are characterized by increased bone resorption, it is not known whether $\mathrm{T} 3$ acts directly in osteoclasts or whether effects on osteoclasts are secondary to the actions of T3 in osteoblasts.

\subsection{Role of TSH on bone}

Thyroid stimulating hormone (TSH) is a ligand hormone between hypothalamic-pituitary axis and the thyroid gland. TSH has long been recognized to act on the thyroid gland to control follicle development and thyroid hormone production and secretion. Beyond thyroid, TSH has also been shown to have additional effects on other tissues. TSH can exert a direct effect on bone metabolism independently of the peripheral thyroid hormone (thyroxine, T4, and triiodothyronine, T3) levels. This effect is mediated through the receptor for binding the thyroid-stimulating hormone (TSH-R), which is a pituitary G proteincoupled transmembrane receptor. Its expression has been demonstrated on osteoblast and osteoclast precursors. The TSH-R haploinsufficient mice display osteoporosis and focal osteosclerosis and thyroid hormone replacement did not restore bone mass but corrected growth deficiency in these animals (Abe et al, 2003). It has been suggested that the effects of TSH on the skeleton are independent of thyroid hormone levels.

In vitro and in vivo studies have provided evidence that TSH has negative effects on both osteoclasts and osteoblasts (Abe et al, 2003; Hase et al, 2006; Sun et al, 2006; Ma et al, 2011). TSH inhibits osteoclastogenesis by attenuating Janus N-terminal kinase (JNK) and NF-KB signaling. The osteoclast-inhibitory actions of TSH are partially mediated also through effects on tumor necrosis factor (TNF)-alpha production as it has been demonstrated in murine models (Abe et al, 2003). Mice lacking the TSHR present osteoporosis, early in embryogenesis, due to increased osteoclast formation (Abe et al, 2003; Hase et al 2006; Ma et al, 2009). These observations have not been confirmed in double-null mice of TSHR and TNF-alpha supporting thus the role of TNF-alpha in increased osteoclastogenesis (Abe et al, 
2003; Hase et al 2006; Ma et al, 2009). Yamoah et al (2008) have recently described RANKLresponsive elements on the TNF alpha gene providing new insights into regulation of TNF transcription in osteoclast formation. The role of TSH on RANKL remains controversial since the administration of the exogenous recombinant TSH in animal models and humans has been shown to increase and in other series to decrease RANKL serum levels (Martini et al, 2008; Sampath et al, 2007; Abe et al, 2003). Role of TSH in osteoblastogenesis seems to be mediated through attenuation of Wnt and VEGF signaling (Abe et al, 2003). Enhanced osteoblastogenesis in TSHR deficiency was found to be associated with increased expression of low-density lipoprotein receptor-like protein-5 and Flk-1 proteins (Abe et al, 2003). Expression of these receptors, but not that of osteoblastic transcription factors, was inhibited by rhTSH. Altogether, these observations suggest that TSH negatively modulates bone turnover, however, further research is warranted to explain in detail the regulatory pathways.

\section{Thyroid hormones and skeletal growth in infancy and adolescence}

In prepubertal children, the linear growth is controlled mainly by GH-IGF-I axis, with influence from glucocorticoids and thyroid hormones. Thyroid hormones were shown to play an essential role for normal onset of the childhood component of growth (Heyerdahl, 1997). Role of the GH/IGF-I axis in the regulation of thyroid gland growth has recently been demonstrated (Boas et al, 2009). During pubertal period, sex steroids are important coregulators of skeletal growth. Age related consequences of thyroid dysfunction on bone development have largely been described. Nevertheless, the exact role of thyroid hormone in the peak bone mass acquisition during childhood and early adulthood is not well understood. The same is for the gender specific action of T3 in the developing skeleton (Gauthier et al, 1999).

Euthyroid status is essential for normal skeletal development and linear growth. Generalized retardation in endochondral and intramembranous ossification associated with alterations in the EGPs, such as reduced thickness, disorganized columns of chondrocytes, and impaired differentiation of hypertrophic chondrocytes, have been reported in hypothyroid status during development (Lewinson et al, 1989; Stevens et al, 2000). The clinical consequences are reduced growth and skeletal abnormalities (Allain \& McGregor, 1993). Theodore Kocher was awarded the Nobel Prize in Medicine in 1909 for his description of consequences of thyroidectomy. He showed the impact of hypothyroidism on the child growth (Kocher, 1883). Hypothyroid children present with the growth retardation and disproportionately short limbs in relation to the trunk. Radiographic skeletal examination may reveal, depending on the age and onset of hypothyroidism, a delayed closure of the fontanelles, enlargement of pituitary fossa and epiphyseal dysgenesis. Reilly \& Smyth have described in 1937 stippled appearance of epiphyses on X-ray films in hypothyroid children. The pathognomonic nature of these changes was later confirmed by Wilkis (Wilkis, 1941). Epiphyseal dysgenesis has been demonstrated in the ossification centers that normally ossify after the onset of the hypothyroid status. Delayed appearance of ossification centers and delayed bone age are also noted in hypothyroid children. BMD 
seems to be also affected by a hypothyroid status during childhood. In one cross-sectional study, BMD was reported to be lower in prepubertal children with congenital hypothyroidism than in controls (Demartini et al, 2007).

Treatment with thyroxine results in a period of rapid catch-up growth, although predicted final height based on midparental height calculations may not be achieved, particularly when hypothyroidism is prolonged (Rivkees et al, 1988). The LT4 replacement for 8 years in children with congenital hypothyroidism did not have a negative effect on BMD for the lumbar spine and the femoral site and on biochemical markers of bone turnover (Leger et al, 1997). The results showed normal serum levels of calcium, phosphate, alkaline phosphatase, parathyroid hormone and 25-hydroxyvitamin D and did not demonstrate any relationship between BMD and L-T4 dosage or biochemical markers of bone formation. These findings were confirmed by other studies reporting no alterations of bone mass in adolescents and young adults with congenital hypothyroidism, treated from the neonatal period (Salerno et al, 2004, Demeester-Mirkine et al, 1990).

On the other hand, thyroid hormone excess results in accelerated skeletal maturation, premature closure of the EGPs and subsequent decrease in longitudinal bone growth with a compromised final adult height (Allain \& McGregor, 1993; O'Shea et al, 1993; Harvey et al, 2002). In severe cases, hyperthyroidism during early childhood may also cause craniosynostosis due to premature fusion of the sutures of the skull (Segni et al 1999). Low bone density values and high bone resorption rates were demonstrated at diagnosis of hyperthyroidism in children and adolescents (Mora et al, 1999). Successful treatment of hyperthyroidism was shown to increase BMD in children and improve the conditions for the best obtainable peak bone mass (Mora et al, 1999).

Consequences of syndrome of resistance to thyroid hormone (RTH) on the skeletal development have been described in literature. RTH results from dominant negative mutations in the carboxyl terminus of the thyroid hormone receptor $\beta$ gene. The mutant receptors are transcriptionally impaired and inhibit thyroid hormone receptor action. RTH is characterized by phenotypic variability including skeletal manifestations (Weiss et Refetoff, 2000). Our current understanding is based mainly on the published case reports. Involvement of the skeleton can cause a short stature, advanced or delayed bone age, increased bone turnover, osteoporosis, fractures, craniofacial abnormalities and craniosynostosis. The clinical variability might be secondary to functional properties of mutant proteins and heterogeneity of cofactors mediating action of TR (Kvistad et al, 2004).

\section{Effects of thyroid dysfunction on bone turnover in adult bone}

\subsection{Hypothyroidism}

Reduced bone turnover in hypothyroidism impairs bone formation and mineralization (Eriksen et al, 1986). Results of population studies indicate an increased fracture risk in hypothyroid individuals (Ahmed et al, 2006; Vestegaard et al 2002, 2005). The association between subclinical hypothyroidism and decreased BMD with increased fracture risk has 
also been reported, but has not been confirmed by others (Lee et al, 2006, 2010; Bertoli et al, 2002). Overall, the literature data have so far presented conflicting results. We will review the current literature and discuss changes in the bone metabolism, BMD and fracture risk in adult men and women with overt and subclinical hypothyroidism.

\subsubsection{Mineral metabolism in hypothyroidism}

Slight perturbations in some parameters of bone and mineral metabolism have been reported in hypothyroid patients. Minor abnormalities of calcium metabolism may exist with slightly elevated serum calcium, PTH and 1,25(OH $)_{2}$ vitamin D, decreased level of alkaline phosphatase, decreased urinary calcium excretion and glomerular filtration rate. The exchangeable pool of calcium and its rate of turnover may be reduced, reflecting decreased bone formation and resorption. However, these changes seem not to be different, even during the treatment, in hypothyroid patients compared to euthyroid controls (Sabuncu et al, 2001).

\subsubsection{Overt hypothyroidism and skeletal changes}

Large population based studies identified an increased fracture risk in individuals with hypothyroidism (Vestegaard et al 2000; 2002). The first of these studies (Vestegaard et al, 2000) analyzed 408 patients with primary hypothyroidism and found a temporary increase in fracture risk within the first 2 years after diagnosis, mainly in the age group $\geq 50$ years, and was limited to the forearms. In the following study (Vestegaard, 2002), 4473 patients with autoimmune hypothyroidism (mean age, $66.1+/-17.3$ ) were shown to present a significantly increased fracture risk up to 8 years prior to diagnosis with a peak around the time of diagnosis. The fracture risk was found to return to normal more than 5 years after its diagnosis.

An increased fracture risk in hypothyroid patients is not probably due to modifications of bone density. There are no convincing literature data as to changes in bone architecture during hypothyroidism. Neuromuscular symptoms and impaired muscle energy metabolism could be responsible for bone changes in this population. Hypothyroid patients have been shown to display impaired neuromuscular response to exercise persisting even after restoration of euthyroid status (Caraccio et al, 2005).

\subsubsection{Subclinical hypothyroidism and skeletal changes}

Subclinical hypothyroidism is a relatively frequent clinical condition, particularly among aged population, characterized by a low-normal free T4 level and a slightly elevated TSH level. The prevalence of subclinical hypothyroidism has been reported between 3.9 and $6.5 \%$ (Hollowell et al, 2002; Huber et al, 2002)

In Trosmo study, Grimnes et al. (2008) have demonstrated that, after multivariate adjustment, 25 out of 950 postmenopausal women with serum TSH above the 97.5 percentile had significantly higher BMD at the femoral neck than women with serum TSH in the 
normal range. However, there was no association between TSH and BMD, and serum TSH as a continuous variable had no effect on BMD.

Bone quality was studied by Nagata et al. using quantitative ultrasound in postmenopausal women with subclinical hypothyroidism. The results demonstrated that calcaneo osteo sono assessment indices of right feet measured by ultrasound bone densitometer decreased according to the increase in TSH concentration. The authors have suggested that hypothyroidism affects bone structure (Nagata et al, 2007).

\subsection{Hyperthyroidism}

Hyperthyroid patients present with an increased bone turnover and a risk for osteoporosis. The activity of osteoblasts and osteoclasts are increased, the latter predominates favoring resorption, negative balance of calcium, and bone loss (Melsen \& Mosekilde, 1977; Mosekilde et al, 1990). Thyrotoxicosis in adults is a recognized cause of high-bone-turnover osteoporosis. Reduced bone mineral density was noted in hyperthyroid patients with an increased susceptibility to fragility fracture (Mosekilde et al, 1990; Vestergaard et al, 2002, 2005).

In both, clinical and subclinical hyperthyroidism, elevation of markers of bone turnover and decreased BMD have been reported (Kumeda et al, 2000; Heemstra et al, 2006; Lee et al, 2006). Previous studies that investigated impact of thyroid dysfunction on BMD and fracture risk did not provide conclusive results. Recently published population studies indicate association of endogenous subclinical hyperthyroidism with an increased fracture risk (Bauer et al, 2001; Jamal et al, 2005; Vadiveloo et al, 2011). Consequences of the hyperthyroid status (overt and subclinical) on bone turnover, BMD and fracture risk will be discussed and compared with the data in healthy population.

\subsubsection{Mineral metabolism in hyperthyroidism}

Hyperthyroidism is associated with impaired mineral metabolism. Increased serum calcium levels have been reported in up to $27 \%$ of hyperthyroid patients (Begic-Karup et al, 2001), but severe and symptomatic hypercalcemia is rare. Concentrations of serum alkaline phosphatase and osteocalcin are also frequently elevated. These findings are reminiscent of those in primary hyperparathyroidism, however, serum parathyroid hormone is mostly low-normal (Iqbal et al, 2003). True primary hyperparathyroidism and thyrotoxicosis may coexist (Beus \& Stack, 2004; Wagner et al, 1999). Decreased plasma 25hydroxycholecalciferol levels observed in hyperthyroidism could participate to the lower intestinal absorption of calcium and osteopenia in these patients (Mohan et al, 2004). Bone resorption markers, urinary pyridinoline and deoxypyridinoline, are increased 7-8 times more than in age and sex matched controls (Kraenzlin et al, 2008). Furthermore, hyperthyroid patients display a greater increase in urinary pyridinoline cross-links than that in serum markers of bone formation (osteocalcin, bone-specific alkaline phosphatase) (Akalin et al, 2002; Kisakol et al, 2003). Altogether, an increased bone turnover in these patients is in favor of osteoclastic bone resorption. 
After initiation of anti-thyroid treatment, biochemical markers of bone resorption, such as urinary hydroxyproline, serum pyridinoline, serum deoxypiridinoline cross-links, have been found to fall, with a subsequent rise of the bone formation markers (Mosekilde et al 1990; Siddiqi et al, 1997; Garnero et al, 1994). Elevation of serum PTH has been reported in some patients with severe thyrotoxicosis under anti-thyroid treatment (Pantazi et al, 2000). This rise in PTH was suggested to play a role in inducing some temporal changes in mineral metabolism and participate to the reversal of the catabolic bone status of hyperthyroidism to anabolic. Furthermore, another study found that in hyperthyroidism, despite normal or high IGF-I levels, IGF-I bioactivity is reduced, probably because of high levels of IGF-binding protein-1 (Miell et al, 1993). Treatment of thyrotoxicosis reverses this abnormality. The rise in IGF-I bioactivity may therefore have a positive effect on the bone metabolism.

\subsubsection{Overt hyperthyroidism and skeletal changes}

Pathological skeletal changes, including osteopenia and osteoporosis, with higher incidence of fracture rates have been reported in hyperthyroid patients. Accordingly, hyperthyroidism was found 2.5-fold more often in postmenopausal women presenting with hip fracture than in controls. Among postmenopausal women, risk of hip fracture was significantly higher in patients with overt untreated hyperthyroidism and a history of past hyperthyroidism (Wejda et al, 1995). These findings were confirmed by a prospective follow-up study realized in 9516 Caucasian women, 65 years of age or older (Cummings et al, 1995). The authors demonstrated a higher risk of hip fracture among women who had previous hyperthyroidism. Another study reported that the prevalence of all types of fractures in patients with a history of thyroid disease was not different from that of control subjects.

However, women with a history of hyperthyroidism or thyroid cancer appeared to have their first fracture earlier than women without thyroid disease (Solomon et al, 1993). Median lumbar BMD in patients with thyrotoxicosis was shown to be $12.6 \%$ lower than that of normal individuals before the initiation of treatment (Krolner et al, 1983). Decreased BMD in hyperthyroid patients was demonstrated particularly in areas consisting of cortical bone. The risk of hip fracture increased significantly with age at diagnosis of hyperthyroidism (Campos-Pastor et al, 1993; Udayakmar et al, 2006; Vestergaard et al, 2002, 2005). The etiology of hyperthyroidism is not believed to play a role in the severity of hyperthyroid bone disease (Jodar et al, 1997).

A recent meta-analysis (Vestergaard et al, 2005) evaluated data regarding BMD and fracture risk in 20 (962 patients) and 5 publications, respectively (62 830 patients and controls). The results showed that patients with hyperthyroidism have a significantly decreased BMD. These values were lower in untreated patients compared to those under treatment, particularly for the lumbar spine (-0.83 vs. $-0.27 \mathrm{Z}$-score) and the femoral site (-0.75 vs. -0.15 Z-score). The risk of hip fracture at the moment of diagnosis of hyperthyroidism was 1.6 (95\% CI 0.7 to 3.4), and the value of BMD alone was associated with a risk of hip fracture corresponding to 1.2 (95\% CI 0.9-1.5). 
Decreased bone density in hyperthyroid patients tended to normalize under treatment (Wejda et al, 1995, Jodar et al, 1997). The improvement of BMD was noted even though no other specific anti-osteoporotic measures were introduced. The type of treatment of hyperthyroidism, iodine 131 or anti-thyroid drugs was not shown to alter the fracture risk (Vestergaard et al, 2005).

\subsubsection{Subclinical hyperthyroidism and skeletal changes}

Subclinical hyperthyroidism is defined as subnormal serum TSH with normal serum free thyroid hormones without signs or symptoms of thyrotoxicosis. Its prevalence in the U.S. population has been reported $0.7 \%$ (Hollowell et al, 2002). By definition, such patients should not have any clinical abnormalities associated with thyrotoxicosis (Biondi et al, 2005). However, a reduced bone mass was reported among postmenopausal patients (Bauer et al 2001). These observations could thus have a broader impact on the healthcare systems, as the subclinical hyperthyroidism is more frequent than overt thyrotoxicosis (Hollowell et al, 2002). Improvement of bone mineral density was shown in postmenopausal women with subclinical hyperthyroidism after normalization of their thyroid function (Faber et al, 1998). These data would justify indications of treatment in the older population. However, the risk/benefit ratio needs to be demonstrated by long-term, randomized studies.

On the other hand, the bone mineral density of the lumbar spine, femoral neck and the midshaft of the radius were not significantly decreased in premenopausal women (Foldes et al, 1993). The impact of subclinical hyperthyroidism in men is less known. A recent work suggests that a serum TSH concentration at the lower end of the reference range may be associated with low BMD in men (Kim et al, 2010).

\section{Impact of thyroid hormone treatment on bone metabolism}

Effects of thyroid replacement therapy or thyroid suppressive therapy on bone mineral density (BMD) are controversial. Results of previous studies are confounded by differences in study design, insufficient prospective data and small numbers of subjects. In the population study by Vestergaard et al (2005), the use of anti-thyroid drugs was associated with a significantly reduced fracture risk, no effect of levothyroxine on fracture risk was observed. No influence of L-thyroxine therapy on BMD was reported in young adults with congenital hypothyroidism (Salerno et al, 2004). Recently published population based casecontrol study has demonstrated a significantly increased fracture risk in adults over 70 years treated by levothyroxine (Turner et al, 2011). Publications on the association between the thyroid replacement and suppressive treatments and the bone mineral metabolism will be discussed.

\subsection{Thyroid hormone replacement therapy}

The objective of thyroid hormone replacement therapy is to normalize TSH levels. Some authors have suggested that treatment with levothyroxine may cause long-term 
osteoporosis, but there is no evidence to support this theory, and studies have shown no difference in bone density or fracture risk in patients undergoing treatment.

Previously, the effects of thyroid hormone treatment upon lumbar spine BMD were studied in a consecutive series of patients with myxedema. Patients with myxoedema did not differ from normal individuals as regards initial lumbar BMD, but levothyroxine-treatment caused a significant reduction in this variable. The median decrease in lumbar BMC after 1 year was $8.9 \%$ (95\% confidence limits $1.5-15.4 \%$, P less than 0.05 ). This loss of bone might be attributed to an inappropriate increase in bone turnover in the euthyroid status (Krolner et al, 1983). Accelerated bone turnover was shown to occur in women with subclinical hypothyroidism during replacement L-T4 treatment and normal TSH levels (Meier et al, 2004; Tarraga Lopez et al, 2011). In these women, bone loss was attributed to an adaptive mechanism on decreased bone turnover in pre-existent hypothyroidism. Finally, a long-term L-T4 treatment in children and adolescents with congenital hypothyroidism, diffuse goiter or with chronic lymphocytic thyroiditis did not affect BMD nor had a negative effect on the attainment of peak bone mass (Kooh et al, 1996; Saggese et al, 1996; Tumer et al, 1999). These results suggest that careful regulation of thyroid replacement is critical. Significant effects of prolonged L-T4-replacement therapy on bone tissue in patients with congenital hypothyroidism can be avoided by careful monitoring of serum TSH and adjustment of doses of L-T4 (Salerno et al, 2004).

\subsection{Thyroid hormone suppressive therapy}

Treatment with thyroid hormones with the objective to suppress TSH levels is used for example after surgery and radioiodine in differentiated thyroid carcinomas. The patients are maintained in subclinical hyperthyroidism, a condition associated with increased bone turnover.

Previous studies indicated that adults receiving high doses of L-T4-replacement therapy may be at risk of excessive bone loss. Reduction in BMD was observed after exogenous administration of high L-T4 doses used to fully suppress TSH in cases of thyroid cancer, goiters or nodules. Further, a review of cross-sectional and prospective studies examining the effect of thyroid hormone suppression on skeletal integrity in adults showed neither significant negative effect nor a decrease in BMD (Greenspan et al, 1990). Conflicting results were reported also in children. A significant reduction in peripheral BMD was found in children and adolescents receiving suppressive doses of L-T4 treatment for endemic goiter, Hashimoto's thyroiditis or thyroid cancer (Radetti et al, 1993).

More recently, suppression of TSH in hyperthyroidism or after thyroid hormone treatment has been shown to result in decrease in BMD and increase in fracture risk in postmenopausal women (Vestergaard et al, 2000; Bauer et al, 2001; Jamal et al, 2005; Kim et al, 2006). Similar results have been demonstrated in premenopausal women and men by Karner et al (2005). Recently realized systematic reviews analyzing effects of subclinical hyperthyroidism showed that postmenopausal women with subclinical hyperthyroidism may present an increased risk, whereas no increased risk has been demonstrated in men and 
premenopausal women (Quan et al, 2002; Heemstra et al, 2006). However, both reviews found methodological differences between different studies, making a structured metaanalysis impossible. Lately, a randomized prospective controlled trial has shown significant adverse effects of TSH suppressive therapy on BMD in women $\geq 50$ years of age (Sugitani et Fujimoto, 2011). However, the results have not been adjusted for confounding factors, such as menopause status, dietary calcium, vitamin D intake, and smoking.

Overall, literature data enhance the hypothesis that low TSH levels may have a deleterious effect on bone homeostasis. Nevertheless, the exact relationship between subclinical hyperthyroidism and osteoporosis remains to be explained.

\section{TSH as a metabolic regulator}

We previously discussed (see paragraph 1.2) the role of TSH in the control of bone remodeling in animal models (Abe E, Marians RC et al, 2003). Systemic administration of TSH to ovariectomised rats has been shown to prevent bone loss and restore bone mass (Sampath et al, 2007; Sun et al, 2008) have demonstrated that intermittent administration of exogenous TSH in ovariectomised rats and mice have anti-resorptive effects. Recent findings indicate that TSH might play a crucial role in bone turnover in humans. Bone loss has been shown in women with polymorphism in the TSHR gene (Onigata et al, 2005).

There is a growing body of evidence that variations of TSH even in its reference range may influence BMD. A higher BMD has been reported in postmenopausal women with TSH within the physiological range comparing to these with the low level of TSH (Baqi et al, 2010). Clinical observations show that patients with subclinical hyperthyroidism and normal circulating thyroid hormone levels display osteoporotic changes (De Menis et al, 1992; Kisakol et al, 2003). Strong correlation between serum TSH and bone status has been demonstrated in postmenopausal women (Bauer et al, 2001; Morris et al, 2007). Based on these findings it has been suggested that it is the suppressed TSH rather than the elevated thyroid hormones that exert a deleterious effect on bone density. In a recent observational study, low-normal TSH values were shown to be associated with high prevalence of vertebral fractures in women with post-menopausal osteoporosis or osteopenia, even after correction for age, BMD, BMI and serum free-thyroxine values (Mazziotti et al, 2010). Svare et al, 2009, in a cross-sectional, population-based study, analyzed 5778 women without and 944 with self-reported thyroid disease aged $\geq 40$ years. Women with the TSH level $<0.50$ $\mathrm{mU} / \mathrm{l}$ had lower forearm BMD than the reference group and the prevalence of osteoporosis was higher in women who reported hyperthyroidism than in women without self-reported thyroid disease. Finally, Kim et al, 2010 investigated the association between serum thyrotropin (TSH) concentration and bone mineral density (BMD) in 1478 healthy euthyroid men in a cross-sectional community based survey. Lumbar spine BMD and femoral neck BMD were shown to increase with TSH level after adjustment for age, weight and height. The odds of lower BMD were significantly increased in subjects with low-normal TSH, when compared to high-normal TSH after adjustment for confounding factors. These results 
suggested that a serum TSH concentration at the lower end of the reference range may be associated with low BMD in men.

The role of TSH on bone metabolism has also been analyzed through markers of bone metabolism after administration of recombinant TSH (rhTSH). TSH has been demonstrated to activate directly osteoblasts according to the increased levels of N-terminal propeptide of type I procollagen (PINP) (Martini et al, 2008). Others showed that TSH promotes the production and activity of alkaline phosphatase and of osteocalcin (Sampath et al, 2007; Abe et al, 2003), while some studies found inhibition of osteoblast differentiation induced by the administration of TSH (Abe et al, 2003). These finding suggested that TSH may enhance the differentiation of osteoblasts precursors.

Clinically, it has been found that the administration of exogenous TSH may have antiresorptive effects of TSH on bone turnover. In women monitored for thyroid carcinoma, a short-term stimulation with rhTSH had inhibitory effect on bone resorption. Acute administration of rhTSH in thyroidectomised postmenopausal women with suppressed endogenous serum TSH resulted in diminution in serum C-telopeptides of type- 1 collagen and increase in bone alkaline phosphatase (Mazziotti et al., 2005). A transient inhibition of bone resorption and increase in osteoblastic activity, measured by markers of bone metabolism, after acute TSH administration was demonstrated also by other studies (Karga et al, 2010; Iakovou et al, 2010; Martini et al, 2008).

Overall, these data constitute the evidence for relationship between TSH and a change in bone mass in humans.

\section{Bone effects of thyroid hormone analogues}

Synthetic analogues of thyroid hormones display tissue-specific actions (Baxter and Webb 2009). They have been developed for their lipid lowering activity by preferential activation of the TR $\beta 1$ isoform in the liver while sparing the TR $\alpha 1$ mediated cardiac effects (Angelin \& Rudling, 2010; Pramfalk et al., 2010; Webb, 2010). Previous animal and human studies have demonstrated that thyromimetics can influence bone metabolism. Skeletal effects of thyroid hormone analogues recently reported in literature on cell lines, animal models and humans are summarized in Table 1.

Previously studied selective thyromimetic, tiratricol (3,5,3'-triiodothyroacetic acid; Triac) was shown to enhance skeletal metabolic activity (Sherman, et al 1997) and to produce adverse effects on bone metabolism (Alvarez et al 2004; Brenta et al 2003; Kawaguchi et al 1994a, 1994b). DITPA, 3,5-diiodothyropropionic acid, has a higher affinity for the TR $\beta$ compared to the TR $\alpha$. Administration of DITPA to humans for 24 weeks was associated with a significant rise in serum osteocalcin, N-telopeptide, and deoxypyridinoline levels, indicating an increased bone turnover (Ladenson el al 2010b). GC-1, [3,5-dimethyl-4-(4'hydroxy-3'isopropylbenzyl)-phenoxy acetic acid], binds TR $\beta 1$ with the same affinity as T3, but TR $\alpha 1$ with a 10-fold lower affinity (Scanlan, 2010). Bone sparing effects in adult female rats have been observed after treatment by GC-1 for 64 days (Freitas et al, 2003). In another 


\begin{tabular}{|c|c|c|c|}
\hline Thyromimetic & Study Design & Skeletal effects & Reference \\
\hline $\begin{array}{l}\text { Tiratricol } \\
\text { (Triac) }\end{array}$ & $\begin{array}{l}\text { Cultured neonatal } \\
\text { mouse calvariae: Triac } \\
\text { vs. T3 }\end{array}$ & $\begin{array}{l}\text { More potent stimulation of } \\
\text { resorption and less potent } \\
\text { stimulation of formation vs. } \\
\text { T3 }\end{array}$ & $\begin{array}{l}\text { Kawaguchi } \\
\text { 1994a }\end{array}$ \\
\hline $\begin{array}{l}\text { Tiratricol } \\
\text { (Triac) }\end{array}$ & $\begin{array}{l}\text { Cultured fetal rat long } \\
\text { bones and neonatal } \\
\text { mouse calvariae; Triac } \\
\text { vs. T3 }\end{array}$ & $\begin{array}{l}\text { Equal or greater stimulation of } \\
\text { bone resorption by Triac than } \\
\text { T3 }\end{array}$ & $\begin{array}{l}\text { Kawaguchi } \\
1994 \text { b }\end{array}$ \\
\hline $\begin{array}{l}\text { Tiratricol } \\
\text { (Triac) }\end{array}$ & Rats; Triac vs. T3 & $\begin{array}{l}\text { Greater increase in beta-CTX } \\
\text { levels, no alteration of BMD }\end{array}$ & $\begin{array}{l}\text { Alvarez } \\
2004\end{array}$ \\
\hline $\begin{array}{l}\text { Tiratricol } \\
\text { (Triac) }\end{array}$ & $\begin{array}{l}\text { Randomized clinical } \\
\text { trial ( } 2 \text { months); } \\
\text { athyreotic patients: } \\
\text { Triac vs. L-T4 }\end{array}$ & $\begin{array}{l}\text { Increased serum osteocalcin } \\
\text { and urinary excretion of } \\
\text { calcium and pyridinium cross- } \\
\text { links }\end{array}$ & $\begin{array}{l}\text { Sherman } \\
1997\end{array}$ \\
\hline $\begin{array}{l}\text { Tiratricol } \\
\text { (Triac) }\end{array}$ & $\begin{array}{l}\text { Randomized clinical } \\
\text { trial (11 months); } \\
\text { euthyroid goitrous } \\
\text { women: } \\
\text { Triac vs. L-T4 }\end{array}$ & $\begin{array}{l}\text { Significant increase in serum } \\
\text { deoxypyridinoline and } \\
\text { significant decrease in hip } \\
\text { bone density, but ns compared } \\
\text { to L-T4; }\end{array}$ & $\begin{array}{l}\text { Brenta } \\
2003\end{array}$ \\
\hline DITPA & $\begin{array}{l}\text { Prospective, controlled, } \\
\text { double-blind clinical } \\
\text { trial ( } 24 \text { weeks): } \\
\text { DITPA vs. placebo }\end{array}$ & $\begin{array}{l}\text { Increase in serum osteocalcin, } \\
\mathrm{N} \text {-telopeptide and } \\
\text { deoxypyridinoline }\end{array}$ & $\begin{array}{l}\text { Ladenson } \\
2010 b\end{array}$ \\
\hline $\begin{array}{l}\text { Sobetirome } \\
(\mathrm{GC}-1)\end{array}$ & $\begin{array}{l}\text { Rat and mouse } \\
\text { osteoblast-like cells }\end{array}$ & $\begin{array}{l}\text { Induction of differentiation } \\
\text { and activity of osteoblasts }\end{array}$ & $\begin{array}{l}\text { Beber } \\
2009\end{array}$ \\
\hline $\begin{array}{l}\text { Sobetirome } \\
\text { (GC-1) }\end{array}$ & $\begin{array}{l}\text { Female adult Wistar } \\
\text { rats; study groups ( } 64 \\
\text { days): } \\
\text { GC-1; T3 ; control }\end{array}$ & $\begin{array}{l}\text { No effects on BMD in L2-L5, } \\
\text { femur, and tibia; no changes in } \\
\text { histomorphometric } \\
\text { parameters of the femur }\end{array}$ & $\begin{array}{l}\text { Freitas } \\
2003\end{array}$ \\
\hline $\begin{array}{l}\text { Sobetirome } \\
\text { (GC-1) }\end{array}$ & $\begin{array}{l}\text { 21-day old female } \\
\text { hypothyroid rats, } \\
\text { treatment for } 5 \text { weeks: } \\
\text { GC-1 vs. placebo }\end{array}$ & $\begin{array}{l}\text { Induction of ossification, } \\
\text { HC differentiation, expression } \\
\text { of collagen II and X mRNA, } \\
\text { increase in EGP thickness }\end{array}$ & $\begin{array}{l}\text { Freitas } \\
2005\end{array}$ \\
\hline $\begin{array}{l}\text { Eprotirome } \\
\text { (KB2115) }\end{array}$ & $\begin{array}{l}\text { Randomized, double- } \\
\text { blind, multicenter 12- } \\
\text { week clinical trial: } \\
\text { Eprotirome vs. placebo }\end{array}$ & $\begin{array}{l}\text { No changes in b-ALP and type } \\
\text { I collagen breakdown product; } \\
\text { ns increase in PINP }\end{array}$ & $\begin{array}{l}\text { Ladenson } \\
2010 \mathrm{a}\end{array}$ \\
\hline
\end{tabular}

Table 1. Skeletal effects of thyroid hormone analogues: b-ALP - bone alcalic phosphatase; BMD bone mineral density; EGP - epiphyseal growth plate; HC - hypertrophic chondrocytes; ns - non significant; PINP - procollagen type I N-terminal propeptide 
study, partial reversion of the skeletal development and maturation defects has been shown in hypothyroid rats after 5 week therapy by GC-1 (Freitas et al 2005). Eprotirome, (KB2115), 3-[[3,5-dibromo-4-[4-hydroxy-3-(1-methylethyl)-phenoxy]-phenyl]-amino]-3-oxopropanoic acid, displays a higher affinity for TR $\beta 1$ isoform with hepatic uptake (Berkenstam 2008). Administration of eprotirome to humans for 12 weeks has not been associated with unfavorable bone effects (Ladenson et al 2010a).

Altogether the data are consistent with potentially adverse skeletal effects of thyroid hormone analogues. However, no conclusive evidence can be drawn and further investigations would be justified to establish an accurate benefice/risk ratio before their clinical use.

\section{Conclusion}

The last decades have seen an increasing interest in the action of thyroid hormones in bone mineral homeostasis. In vivo and in vitro studies in cell lines as well as animal models have demonstrated a critical role of thyroid hormones, TSH and their receptors in the skeletal growth and its maintenance. However, many of the molecular mechanisms of thyroid hormone action remain still poorly defined.

Clinical studies, consistently with animal data, indicate a close association between thyroid status and bone metabolism. Thyrotoxicosis results in an increased bone turnover, osteoporosis and a risk of fragility fracture. Thyroid hormone deficiency decreases bone turnover with a subsequent risk of bone fragility. Exogenous administration of suppressive doses of thyroxine was shown to negatively influences BMD and bone turnover. In future, prospective studies a prolonged time of observation will be necessary, as well as to increase the number of studied patients, in order to better assess the relative risk of osteoporosis in patients undergoing TSH-suppressive treatment. Another question that remains to be answered is if there is a benefit from treatment of subclinical thyroid disease on skeletal health.

Finally, thyroid hormone analogues represent a promising therapeutic option for their lipid lowering activity. Nevertheless, literature data suggest their potentially adverse skeletal effects. No conclusive evidence can be drawn and further investigations would be justified to establish an accurate benefice/risk ratio before their clinical use.

\section{Author details}

Eva Feigerlova, Marc Klein, Anna Angelousi, Lelia Groza and Georges Weryha* Department of Endocrinology, CHU Nancy, Vandoeuvre, France

Bruno Leheup

Department of Pediatric Endocrinology, CHU Nancy, Vandoeuvre, France

\footnotetext{
* Corresponding Author
} 


\section{References}

[1] Abe E, Marians RC, Yu W, Wu XB, Ando T, Li Y, Iqbal J, Eldeiry L, Rajendren G, Blair HC, Davies TF, Zaidi M. (2003) TSH is a negative regulator of skeletal remodeling. Cell 115: 151-162.

[2] Abu EO, Bord S, Horner A, Chatterjee VKK, and Compston JE (1997) The expression of thyroid hormone receptors in human bone. Bone 21: 137-142.

[3] Ahmed LA, Schirmer H, Berntsen GK et al (2006) Self-reported diseases and the risk of non-vertebral fractures: the Tromso study. Osteoporos Int 17: 46-53.

[4] Akalin A, Colak O, Alatas O, Efe B (2002) Bone remodeling markers and serum cytokines in patients with hyperthyroidism. Clin Endocrinol 57:125-129

[5] Allain TJ, Chambers TJ, Flanagan AM, McGregor AM (1992) Tri-iodothyronine stimulates rat osteoclastic bone resorption by an indirect effect. J Endocrinol 133:327331.

[6] Allain TJ, McGregor AM (1993) Thyroid hormones and bone. J Endocrinol 139:9-18.

[7] Alvarez L, Burgueño A, Zeni S, Randi AS, Hernández S, Hockl P, et al (2004) Comparison of the effects of 3,5,3'-triiodothyroacetic Acid and triiodothyronine on goiter prevention and involution and on hepatic and skeletal parameters in rats. Horm. Metab. Res. 36:291-7.

[8] Angelin, B., \& Rudling, M. (2010). Lipid lowering with thyroid hormone and thyromimetics. Curr Opin Lipidol 21(6), 499-506.

[9] Ballock R, Mita BC, Zhou X, Chen DH, and Mink LM (1999) Expression of thyroid hormone receptor isoforms in rat growth plate cartilage in vivo. J Bone Miner Res 14: 1550-1556, 1999.

[10] Ballock RT, Reddi AH (1994) Thyroxine is the serum factor that regulates morphogenesis of columnar cartilage from isolated chondrocytes in chemically defined medium. J Cell Biol 126:1311-1318.

[11] Ballock RT, Zhou X, Mink LM, Chen DH, Mita BC, Stewart MC (2000) Expression of cyclin-dependent kinase inhibitors in epiphyseal chondrocytes induced to terminally differentiate with thyroid hormone. Endocrinology. 141:4552-7.

[12] Baqi L, Payer J, Killinger Z, Susienkova K et al (2010) The level of TSH appeared favourable in maintaining bone mineral density in postmenopausal women. Endocr Regul. 44: 9-15.

[13] Barnard, J.C. et al. (2005) Thyroid hormones regulate fibroblast growth factor receptor signaling during chondrogenesis. Endocrinology 146: 5568-5580

[14] Bassett JH, Williams GR (2003) The molecular actions of thyroid hormone in bone. Trends Endocrinol Metab 14: 356-364.

[15] Bassett, J.H. et al. (2007a) Thyroid hormone excess rather than thyrotropin deficiency induces osteoporosis in hyperthyroidism. Mol. Endocrinol. 21: 1095-1107

[16] Bassett, J.H. et al. (2007b) Thyroid status during skeletal development determines adult bone structure and mineralization. Mol. Endocrinol. 21: 1893-1904

[17] Bauer DC, Ettinger B, Nevitt MC et al (2001) Risk for fracture in women with low serum levels of thyroid-stimulating hormone. Ann Intern Med134: 561-568. 
[18] Baxter, J. D., \& Webb, P. (2009). Thyroid hormone mimetics: Potential applications in atherosclerosis, obesity and type 2 diabetes. Nat Rev Drug Discov 8(4), 308-320.

[19] Beber EH, Capelo LP, Fonseca TL, Costa CC, Lotfi CF, Scanlan TS, et al (2009) The thyroid hormone receptor (TR) beta-selective agonist GC-1 inhibits proliferation but induces differentiation and TR beta mRNA expression in mouse and rat osteoblast-like cells. Calcif. Tissue Int. 84:324-33

[20] Begic-Karup S, Wagner B, Raber W, Schneider B, Hamwi A, Waldhäusl W, Vierhapper $H$ (2001) Serum calcium in thyroid disease. Wien Klin Wochenschr. 113(1-2):65-8.

[21] Berkenstam, A., Kristensen, J., Mellstrom, K., Carlsson, B., Malm, J., Rehnmark, S., et al. (2008). The thyroid hormone mimetic compound KB2115 lowers plasma LDL cholesterol and stimulates bile acid synthesis without cardiac effects in humans. Proc Natl Acad Sci U S A 105(2), 663-667.

[22] Bertoli A, Fusco A, Andreoli A, Magnani A et al (2002) Effect of subclinical hypothyroidism and obesity on whole-body and regional bone mineral content. Horm Res. 57:79-84.

[23] Beus KS, Stack BC Jr (2004) Synchronous thyroid pathology in patients presenting with primary hyperparathyroidism. Am J Otolaryngol. 25:308-12.

[24] Biondi B, Palmieri EA, Klain M, Schlumberger M, Filetti S, Lombardi G (2005) Subclinical hyperthyroidism: clinical features and treatment options. Eur J Endocrinol 152:1-9.

[25] Boas M et al (2009) Association of Thyroid Gland Volume, Serum Insulin-Like Growth Factor-I, and Anthropometric Variables in Euthyroid Prepubertal Children. J Clin Endocrinol Metab 94: 4031-4035.

[26] Bookout, A.L. et al. (2006) Anatomical profiling of nuclear receptor expression reveals a hierarchical transcriptional network. Cell 126: 789-799

[27] Bradley DJ, Towle HC, \& Young WS 3rd (1992) Spatial and temporal expression of alpha- and beta-thyroid hormone receptor mRNAs, including the beta 2-subtype, in the developing mammalian nervous system. J Neurosci 12: 2288-2302

[28] Brenta G, Schnitman M, Fretes O, Facco E, Gurfinkel M, Damilano S, et al (2003) Comparative efficacy and side effects of the treatment of euthyroid goiter with levothyroxine or triiodothyroacetic acid. J. Clin. Endocrinol. Metab. 88:5287-92.

[29] Britto JM, Fenton AJ, Holloway WR, Nicholson GC (1994) Osteoblasts mediate thyroid hormone stimulation of osteoclastic bone resorption. Endocrinology 134:169-176.

[30] Campos-Pastor MM, Munoz-Torres M, Escobar-Jimenez F, et al (1993) Bone mass in females with different thyroid disorders: influence of menopausal status. Bone and Mineral 21:1-8.

[31] Caraccio N, Natali A, Sironi A, et al (2005) Muscle metabolism and exercise tolerance in subclinical hypothyroidism: a controlled trial of levothyroxine. J Clin Endocrinol Metab 90:4057-62

[32] Chassande O, Fraichard A, Gauthier K, Flamant F, Legrand C, Savatier P, Laudet V, Samarut J (1997) Identification of transcripts initiated from an internal promoter in the c-erbA alpha locus that encode inhibitors of retinoic acid receptor-alpha and triiodothyronine receptor activities. Mol Endocrinol 11:1278-1290. 
[33] Cheng SY, Leonard JL, \& Davis PJ (2010) Molecular aspects of thyroid hormone actions. Endocr Rev 31: 139-170

[34] Cummings SR, Nevitt MC, Browner WS, et al (1995) Risk factors for hip fracture in white women. Study of Osteoporotic Fractures Research Group. N Engl J Med 332:76773.

[35] Demartini Ade A, Kulak CA, Borba VC, Cat MN, Dondoni RS, Sandrini R, et al (2007) Bone mineral density of children and adolescents with congenital hypothyroidism. Arq Bras Endocrinol Metabol. 51:1084-92.

[36] De Menis E, Da Rin G, Roiter I, et al. (1992) Bone turnover in overt and subclinical hyperthyroidism due to autonomous thyroid adenoma. Horm Res 37:217-220.

[37] Demeester-Mirkine N, Bergmann P, Body JJ, et al (1990) Calcitonin and bone mass status in congenital hypothyroidism. Calcif Tissue Int 46:222-6

[38] Eriksen EF, Mosekilde L, Melsen F (1986) Kinetics of trabecular bone resorption and formation in hypothyroidism: evidence for a positive balance per remodeling cycle. Bone 7: 101-108.

[39] Faber J, Jensen IW, Petersen L, Nygaard B, Hegedüs L, Siersbaek-Nielsen K (1998) Normalization of serum thyrotrophin by means of radioiodine treatment in subclinical hyperthyroidism: effect on bone loss in postmenopausal women. Clin Endocrinol (Oxf). 1998 48:285-90.

[40] Flamant F, Poguet AL, Plateroti M, Chassande O, Gauthier K, Streichenberger N, Mansouri A, Samarut J (2002) Congenital hypothyroid Pax8(-/-) mutant mice can be rescued by inactivating the TRalpha gene. Mol Endocrinol 16:24-32.

[41] Foldes J, Tarjan G, Szathmari M, et al (1993) Bone mineral density in patients with endogenous subclinical hyperthyroidism: is this thyroid status a risk factor for osteoporosis? Clin Endocrinol (Oxf) 39:521-7.

[42] Forrest D, Erway LC, Ng L, Altschuler R, Curran T (1996) Thyroid hormone receptor beta is essential for development of auditory function. Nat Genet 13:354-357.

[43] Freitas FRS, Capelo LP, O'Shea PJ, Jorgetti V, Moriscot AS, Scanlan TS, et al. (2005) The thyroid hormone receptor beta-specific agonist GC-1 selectively affects the bone development of hypothyroid rats. J. Bone Miner. Res. 20:294-304.

[44] Freitas FRS, Moriscot AS, Jorgetti V, Soares AG, Passarelli M, Scanlan TS, et al (2003) Spared bone mass in rats treated with thyroid hormone receptor TR beta-selective compound GC-1. Am. J. Physiol. Endocrinol. Metab.285:E1135-1141.

[45] Glass CK, Franco R, Weinberger C, Albert VR, Evans RM, Rosenfeld MG (1987) A c-erbA binding site in rat growth hormone gene mediates trans-activation by thyroid hormone. Nature 329:738-741.

[46] Garnero P, Vassy V, Bertholin A, Riou JP, Delmas PD (1994) Markers of bone turnover in hyperthyroidism an the effects of treatment. J Clin Endocrinol Metab. 78:955-959.

[47] Gauthier, K. et al. (1999) Different functions for the thyroid hormone receptors TRalpha and TRbeta in the control of thyroid hormone production and post-natal development. EMBO J. 18, 623-631

[48] Gauthier K, Plateroti M, Harvey CB, Williams GR, Weiss RE, Refetoff S, Willott JF, Sundin V, Roux JP, Malaval L, Hara M, Samarut J, Chassande O (2001) Genetic analysis 
reveals different functions for the products of the thyroid hormone receptor alpha locus. Mol Cell Biol 21:4748-4760.

[49] Gothe S, Wang Z, Ng L, Kindblom JM, Barros AC, Ohlsson C, Vennstrom B, Forrest D (1999) Mice devoid of all known thyroid hormone receptors are viable but exhibit disorders of the pituitary-thyroid axis, growth, and bone maturation. Genes Dev 13:1329-1341.

[50] Gouveia CH, Schultz JJ, Bianco AC, Brent GA (2001) Thyroid hormone stimulation of osteocalcin gene expression in ROS17/2.8 cells is mediated by transcriptional and posttranscriptional mechanisms. J Endocrinol 170:667-675

[51] Greenspan SL \& Greenspan FS (1999) The effect of thyroid hormone on skeletal integrity. Annals of Internal Medicine 130:750-758.

[52] Grimnes G, Emaus N, Joakimsen RM, Figenschau Y, Jorde R (2008) The relationship between serum TSH and bone mineral density in men and postmenopausal women: The Tromsø study. Thyroid. 18:1147-55.

[53] Harvey CB, O'Shea PJ, Scott AJ, Robson H, Siebler T, Shalet SM, Samarut J, Chassande O, Williams GR (2002) Molecular mechanisms of thyroid hormone effects on bone growth and function. Mol Genet Metab 75:17-30.

[54] Hase H, Ando T, Eldeiry L, Brebene A, Peng Y, Liu L, Amano H, Davies TF, Sun L, Zaidi M, Abe E (2006) TNF mediates the skeletal effects of thyroid-stimulating hormone. Proc Natl Acad Sci USA 103:12849-12854.

[55] Heemstra KA, Hamdy NA, Romijn JA \& Smit JW (2006) The effects of thyrotropinsuppressive therapy on bone metabolism in patients with well-differentiated thyroid carcinoma. Thyroid 16:583-591.

[56] Heyerdahl S (1997) Linear growth in early treated children with congenital hypothyroidism. Acta Paediatr. 86:479-83.

[57] Himeno, M. et al. (2002) Impaired vascular invasion of Cbfa1-deficient cartilage engrafted in the spleen. J. Bone Miner. Res. 17, 1297-1305

[58] Hollowell JG, Staehling NW, Flanders WD, Hannon WH, Gunter EW, Spencer CA, Braverman LE (2002) Serum TSH, T(4), and thyroid antibodies in the United Statuss population (1988 to 1994): National Health and Nutrition Examination Survey (NHANES III). J Clin Endocrinol Metab.87:489-99.

[59] Huber G, Staub JJ, Meier C, Mitrache C, Guglielmetti M, Huber P, Braverman LE (2002) Prospective study of the spontaneous course of subclinical hypothyroidism: prognostic value of thyrotropin, thyroid reserve, and thyroid antibodies. J Clin Endocrinol Metab 87:3221-6.

[60] Iakovou I, Chrisoulidou A, Balaris V, Balaris C, Doumas A, Karatzas N (2010) Acute effects of recombinant human TSH on bone markers in differentiated thyroid cancer. Hell J Nucl Med 13:208-12.

[61] Iqbal AA, Burgess EH, Gallina DL, Nanes MS, Cook CB (2003) Hypercalcemia in hyperthyroidism: patterns of serum calcium, parathyroid hormone, and 1,25dihydroxyvitamin D3 levels during management of thyrotoxicosis. Endocr Pract 9:51721. 
[62] Jamal SA, Leiter RE, Bayoumi AM et al (2005) Clinical utility of laboratory testing in women with osteoporosis. Osteoporos Int 16: 534-540.

[63] Jodar E, Munoz-Torres M, Escobar-Jimenez F, et al (1997) Bone loss in hyperthyroid patients and in former hyperthyroid patients controlled on medical therapy: influence of aetiology and menopause. Clin Endocrinol (Oxf) 47: 279-85.

[64] Karga H, Papaioannou G, Polymeris A, Papamichael K, Karpouza A, Samouilidou E, Papaioannou P (2010) The effects of recombinant human TSH on bone turnover in patients after thyroidectomy. J Bone Miner Metab 28:35-41.

[65] Karner I, Hrgović Z, Sijanović S, Buković D, Klobucar A, Usadel KH, Fassbender WJ (2005) Bone mineral density changes and bone turnover in thyroid carcinoma patients treated with supraphysiologic doses of thyroxine. Eur J Med Res. 10:480-8.

[66] Kawaguchi H, Pilbeam CC, Raisz LG (1994a) Anabolic effects of 3,3',5-triiodothyronine and triiodothyroacetic acid in cultured neonatal mouse parietal bones. Endocrinology 135: 971-6.

[67] Kawaguchi H, Pilbeam CC, Woodiel FN, Raisz LG (1994b) Comparison of the effects of 3,5,3'-triiodothyroacetic acid and triiodothyronine on bone resorption in cultured fetal rat long bones and neonatal mouse calvariae. J. Bone Miner. Res. 9:247-53.

[68] Kim DJ, Khang YH, Koh JM, Shong YK, Kim GS (2006) Low normal TSH levels are associated with low bone mineral density in healthy postmenopausal women. Clin Endocrinol (Oxf) 64:86-90

[69] Kim BJ, Lee SH, Bae SJ, Kim HK, Choe JW, Kim HY, Koh JM, Kim GS (2010) The association between serum thyrotropin (TSH) levels and bone mineral density in healthy euthyroid men. Clin Endocrinol (Oxf). 73:396-403.

[70] Kindblom JM, Gothe S, Forrest D, Tornell J, Vennstrom B, Ohlsson C (2001) GH substitution reverses the growth phenotype but not the defective ossification in thyroid hormone receptor alpha 1/--beta ${ }^{-/-}$mice. J Endocrinol 171:15-22.

[71] Kisakol G, Kaya A, Gonen S, Tunc R (2003) Bone and calcium metabolism in subclinical autoimmune hyperthyroidism and hypothyroidism. Endocr J 50:657-661.

[72] Kocher T (1883) Ueber Kropfexstirpation und ihre Folgen. Arch Klin Chir 29:254.

[73] Koenig RJ, Brent GA, Warne RL, Larsen PR, Moore DD (1987) Thyroid hormone receptor binds to a site in the rat growth hormone promoter required for induction by thyroid hormone. Proc Natl Acad Sci USA 84:5670-5674

[74] Kooh SW, Brnjac L, Ehlrich RM, Qureshi R \& Krishnan S (1996) Bone mass in children with congenital hypothyroidism treated with thyroxine since birth. Journal of Pediatric Endocrinology and Metabolism 9:59-62.

[75] Kraenzlin ME, Kraenzlin CA, Meier C, Giunta C, Steinmann B (2008) Automated HPLC assay for urinary collagen cross-links: effect of age, menopause, and metabolic bone diseases. Clin Chem 54:1546-1553.

[76] Krolner B, Jorgensen JV, Nielsen SP (1983) Spinal bone mineral content in myxedema and thyrotoxicosis. Effects of thyroid hormone(s) and anti-thyroid treatment. Clin Endocrinol (Oxf) 18:439-46.

[77] Kumeda Y, Inaba M, Tahara H et al (2000) Persistent increase in bone turnover in Graves' patients with subclinical hyperthyroidism. J Clin Endocrinol Metab 85:4157-61. 
[78] Kvistad PH, Lovas K, Boman H et al (2004) Retarded bone growth in thyroid hormone resistance. A clinical study of a large family with a novel thyroid hormone receptor mutation. Eur J Endocrinol 150: 425-430.

[79] Ladenson PW, Kristensen JD, Ridgway EC, Olsson AG, Carlsson B, Klein I, et al (2010a) Use of the thyroid hormone analogue eprotirome in statin-treated dyslipidemia. $\mathrm{N}$. Engl. J. Med 362: 906-16.

[80] Ladenson PW, McCarren M, Morkin E, Edson RG, Shih M-C, Warren SR, et al (2010b) Effects of the thyromimetic agent diiodothyropropionic acid on body weight, body mass index, and serum lipoproteins: a pilot prospective, randomized, controlled study. J Clin Endocrinol Metab. 95:1349-54.

[81] Lassova, L. et al. (2009) Thyroid hormone treatment of cultured chondrocytes mimics in vivo stimulation of collagen $\mathrm{X}$ mRNA by increasing BMP 4 expression. J. Cell. Physiol. 219, 595-605

[82] Lazar MA (1993) Thyroid hormone receptors: Multiple forms, multiple possibilities. Endocr Rev 14: 184-193.

[83] Lazar MA, \& Chin WW (1990) Nuclear thyroid hormone receptors. J Clin Invest 86: 1777-1782.

[84] Lee JS, Buzková P, Fink HA, Vu J, Carbone L, Chen Z et al (2010) Subclinical thyroid dysfunction and incident hip fracture in older adults. Arch Intern Med. 170:1876-83.

[85] Lee WY, Oh KW, Rhee EJ, Jung CH, Kim SW et al (2006) Relationship between subclinical thyroid dysfunction and femoral neck bone mineral density in women. Archives of Medical Research 37:511-516.

[86] Leger J, Ruiz JC, Guibourdenche J, Kindermans C, Garabedian M, Czernichow P (1997) Bone mineral density and metabolism in children with congenital hypothyroidism after prolonged L-thyroxine therapy. Acta Paediatr. 86:704-10.

[87] Lewinson D, Harel Z, Shenzer P, Silbermann M, Hochberg Z (1989) Effect of thyroid hormone and growth hormone on recovery from hypothyroidism of epiphyseal growth plate cartilage and its adjacent bone. Endocrinology 124:937-945.

[88] Liu JP, Baker J, Perkins AS, Robertson EJ, Efstratiadis A (1993) Mice carrying null mutations of the genes encoding insulin-like growth factor I (Igf-1) and type 1 IGF receptor (Igf1r). Cell 75:59-72.

[89] Ma R, Latif R, Zaidi M, Davies T (2009) Thyroid and bone: TSH inhibits osteoclastogenesis from embryonic stem cells. Presented at the 91st Annual Meeting of the Endocrine Society. Washington DC; June 10-13, 2009.

[90] Ma R, Morshed S, Latif R, Zaidi M, Davies TF (2011) The influence of thyroidstimulating hormone and thyroid-stimulating hormone receptor antibodies on osteoclastogenesis. Thyroid 21:897-906.

[91] Makihira, S. et al. (2003) Thyroid hormone enhances aggrecanase-2/ADAM-TS5 expression and proteoglycan degradation in growth plate cartilage. Endocrinology 144, 2480-2488

[92] Martini G, Gennari L, De Paola V, Pilli T, Salvadori S, Merlotti D, Valleggi F, Campagna S, Franci B, Avanzati A, Nuti R, Pacini F (2008) The effects of recombinant TSH on bone turnover markers and serum osteoprotegerin and RANKL levels. Thyroid. 18:455-60. 
[93] Mazziotti G, Sorvillo F, Piscopo M, Cioffi M, Pilla P, Biondi B, Iorio S, Giustina A, Amato G, Carella C (2005) Recombinant human TSH modulates in vivo C-telopeptides of type- 1 collagen and bone alkaline phosphatase, but not osteoprotegerin production in postmenopausal women monitored for differentiated thyroid carcinoma. J Bone and Min Res 20:480-486.

[94] Mazziotti G, Porcelli T, Patelli I, Vescovi PP, Giustina A (2010) Serum TSH values and risk of vertebral fractures in euthyroid post-menopausal women with low bone mineral density. Bone. 46:747-51.

[95] Meier C, Beat M, Guglielmetti M, Christ-Crain M, Staub JJ, Kraenzlin M. (2004) Restoration of euthyroidism accelerates bone turnover in patients with subclinical hypothyroidism: a randomized controlled trial. Osteoporosis International 15:209-216.

[96] Melsen F, Mosekilde L (1977) Morphometric and dynamic studies of bone changes in hyperthyroidism. Acta Pathol Microbiol Scand A. 85A:141-50.

[97] Miell JP, Taylor AM, Zini M, Maheshwari G, Ross RJM, Valcani R (1993) Effects of hypothyroidism and hyperthyroidism on insulin-like growth factors (IGFs) and growth hormone- and IGF-binding proteins. J Clin Endocrinol Metab. 76:950 -955.

[98] Milne M, Kang MI, Quail JM, Baran DT (1998) Thyroid hormone excess increases insulin-like growth factor I transcripts in bone marrow cell cultures: divergent effects on vertebral and femoral cell cultures. Endocrinology 139:2527-2534

[99] Milne M, Quail JM, Rosen CJ, Baran DT (2001) Insulin-like growth factor binding proteins in femoral and vertebral bone marrow stromal cells: expression and regulation by thyroid hormone and dexamethasone. J Cell Biochem. 81:229-40.

[100] Mohan HK, Groves AM, Fogelman I, Clarke SE (2004) Thyroid hormone and parathyroid hormone competing to maintain calcium levels in the presence of vitamin D deficiency. Thyroid 14:789-91.

[101] Mora S, Weber G, Marenzi K, Signorini E, Rovelli R, Proverbio MC \& Chiumello G (1999) Longitudinal changes of bone density and bone resorption in hyperthyroid girls during treatment. Journal of Bone and Mineral Research 14: 1971-1977.

[102] Morris MS (2007) The association between serum thyroid stimulating hormone in its reference range and bone status in postmenopausal American women. Bone 40:11281134.

[103] Mosekilde L, Eriksen EF, Charles P. Effects of thyroid hormones on bone and mineral metabolism. Endocrinol Metab Clin North Am 1990; 19: 35-63.

[104] Murphy E, Williams GR. The thyroid and the skeleton. Clin Endocrinol (Oxf) 2004; 61: 285-298.

[105] Nagata M, Suzuki A, Sekiguchi S, Ono Y, Nishiwaki-Yasuda K, Itoi T, et al (2007) Subclinical hypothyroidism is related to lower heel QUS in postmenopausal women. Endocr J 54:625-30.

[106] Onigata K, Kowasi T, Nishiyama S, Micuno H, Morikawa A. Bone mineral density in human cases with TSH receptor gene mutations. Proceedings of the New York Academy of Sciences 1rst Conference on Skeletal Development and Remodeling in Health, Disease, and Aging, May 18-21, 2005, New York, NY, USA. 
[107] O'Shea PJ, Harvey CB, Suzuki H, Kaneshige M, Kaneshige K, Cheng SY, Williams GR (2003) A thyrotoxic skeletal phenotype of advanced bone formation in mice with resistance to thyroid hormone. Mol Endocrinol 17:1410-1424.

[108] O'Shea PJ, Williams GR (2002) Insight into the physiological actions of thyroid hormone receptors from genetically modified mice. J Endocrinol 175:553-570.

[109] O'Shea, P.J. et al. (2005) Contrasting skeletal phenotypes in mice with an identical mutation targeted to thyroid hormone receptor alpha1 or beta. Mol. Endocrinol. 19, 3045-3059

[110] O'Shea, P.J. et al. (2006) Characterization of skeletal phenotypes of TRalpha1 and TRbeta mutant mice: implications for tissue thyroid status and T3 target gene expression. Nucl. Receptor Signal. 4, e011

[111] Pantazi H, Papapetrou PD (2000) Changes in parameters of bone and mineral metabolism during therapy for hyperthyroidism. J Clin Endocrinol Metab. 85:1099-106.

[112] Pereira RC, Jorgetti V, Canalis E (1999) Triiodothyronine induces collagenase-3 and gelatinase B expression in murine osteoblasts. Am J Physiol 277:E496-E504

[113] Pramfalk C, Pedrelli M, \& Parini P (2011) Role of thyroid receptor beta in lipid metabolism. Biochim Biophys Acta 1812:929-37

[114] Radetti G, Castellan C, Tato` L, Platter K, Gentili L \& Adami S (1993) Bone mineral density in children and adolescent females treated with high doses of L-thyroxine. Hormon Research 39:127-131.

[115] Ray RD, Asling CW, Walker DG, Simpson ME, Li CH, Evans HM (1954) Growth and differentiation of the skeleton in thyroidectomized-hypophysectomized rats treated with thyroxin, growth hormone, and combination. J Bone Joint Surg Am 36:94-103

[116] Rivkees SA, Bode HH, Crawford JD (1988) Long-term growth in juvenile acquired hypothyroidism: the failure to achieve normal adult stature. N Engl J med 3:599-602.

[117] Robson H, Siebler T, Stevens DA et al (2000) Thyroid hormone acts directly on growth plate chondrocytes to promote hypertrophic differentiation and inhibit clonal expansion and cell proliferation. Endocrinology 141:3887-3897.

[118] Sabuncu T, Aksoy N, Arikan E, Ugur B, Tasan E, Hatemi H (2001) Early changes in parameters of bone and mineral metabolism during therapy for hyper- and hypothyroidism. Endocr Res. 27:203-13.

[119] Saggese G, Bertelloni S, Baroncelli GI, Costa S \& Ceccarelli C (1996) Bone mineral denisty in adolescent females treated with L-thyroxine: a longitudinal study. European Journal of Pediatrics 155: 452-457.

[120] Salerno M, Lettiero T, Esposito-del Puente A et al. ( 2004) Effect of long-term Lthyroxine treatment on bone mineral density in young adults with congenital hypothyroidism. European Journal of Endocrinology 151:689-694.

[121] Sampath TK, Simic P, Sendak R, Draca N, Bowe AE, O'Brien S, Schiavi SC, McPherson JM, Vukicevic S (2007) Thyroid-stimulating hormone restores bone volume, microarchitecture, and strength in aged ovariectomized rats. J Bone Miner Res. 22:84959.

[122] Sap J, Munoz A, Damm K, Goldberg Y, Ghysdael J, Leutz A, et al. (1986) The c-erb-A protein is a high-affinity receptor for thyroid hormone. Nature 324: 635-640. 
[123] Scanlan TS (2010). Sobetirome: A case history of bench-to-clinic drug discovery and development. Heart Fail Rev 15(2), 177-182.

[124] Segni M et al. (1999) Special features of Graves' disease in early childhood. Thyroid 9: 871-877

[125] Sherman SI, Ringel MD, Smith MJ, Kopelen HA, Zoghbi WA, Ladenson PW (1997) Augmented hepatic and skeletal thyromimetic effects of tiratricol in comparison with levothyroxine. J. Clin. Endocrinol. Metab. 82:2153-8.

[126] Siddiqi A, Burrin JM, Noonan K, James I, Wood DF, Price CP, Monson JP (1997) A longitudinal study of markers of bone turnover in Graves' disease and their value in predicting bone mineral density. J Clin Endocrinol Metab. 82:753-759.

[127] Siddiqi A, Burrin JM, Wood DF, Monson JP (1998) Tri-iodothyronine regulates the production of interleukin- 6 and interleukin- 8 in human bone marrow stromal and osteoblast-like cells. J Endocrinol. 157:453-61.

[128] Siddiqi A, Parsons MP, Lewis JL et al. (2002) TR expression and function in human bone marrow stromal and osteoblast- like cells. J Clin Endocrinol Metab 87: 906-914.

[129] Sjogren K, Bohlooly YM, Olsson B, Coschigano K, Tornell J, Mohan S, Isaksson OG, Baumann G, Kopchick J, Ohlsson C (2000) Disproportional skeletal growth and markedly decreased bone mineral content in growth hormone receptor-/- mice. Biochem Biophys Res Commun 267:603-608.

[130] Solomon BL, Wartofsky L, Burman KD (1993) Prevalence of fractures in postmenopausal women with thyroid disease. Thyroid. 3:17-23.

[131] Stevens DA, Hasserjian RP, Robson H, Siebler T, Shalet SM, Williams GR (2000) Thyroid hormones regulate hypertrophic chondrocyte differentiation and expression of parathyroid hormone-related peptide and its receptor during endochondral bone formation. J Bone Miner Res 15:2431-2442.

[132] Stevens, D.A. et al. (2003) Thyroid hormone activates fibroblast growth factor receptor1 in bone. Mol. Endocrinol. 17, 1751-1766

[133] St Germain, D.L. et al. (2009) Defining the roles of the iodothyronine deiodinases: current concepts and challenges. Endocrinology 150: 1097-1107

[134] Sugitani I, Fujimoto Y (2008) Effect of postoperative thyrotropin suppressive therapy on bone mineral density in patients with papillary thyroid carcinoma: a prospective controlled study. Surgery. 150:1250-7.

[135] Sun L et al. (2008) Intermittent recombinant TSH injections prevent ovariectomyinduced bone loss. PNAS. 105:4289-4294.

[136] Svare A, Nilsen TI, Bjøro T, Forsmo S, Schei B, Langhammer A (2009) Hyperthyroid levels of TSH correlate with low bone mineral density: the HUNT 2 study. Eur J Endocrinol. 161:779-86.

[137] Tárraga López PJ, López CF, de Mora FN, Montes JA, Albero JS, Mañez AN, Casas AG (2011) Osteoporosis in patients with subclinical hypothyroidism treated with thyroid hormone. Clin Cases Miner Bone Metab. 8:44-8.

[138] Thorngren KG, Hansson LI 1973 Effect of thyroxine and growth hormone on longitudinal bone growth in the hypophysectomized rat. Acta Endocrinol (Copenh) 74:24-40. 
[139] Thorngren KG, Hansson LI 1974 Bioassay of growth hormone II. Determination of longitudinal bone growth with tetracycline in thyroxine-treated hypophysectomized rats. Acta Endocrinol (Copenh) 75:669-682.

[140] Thompson CC, Weinberger C, Lebo R, \& Evans RM (1987) Identification of a novel thyroid hormone receptor expressed in the mammalian central nervous system. Science 237:1610-1614.

[141] Tumer L, Hasanoglu A, Cinaz P \& Bideci A (1999) Bone mineral density and metabolism in children treated with L-thyroxine. Journal of Pediatric Endocrinology and Metabolism 12:519-523.

[142] Turner MR et al. (2011) Levothyroxine dose and risk of fractures in older adults: nested case-control study. BMJ. 342:d2238

[143] Udayakumar N, Chandrasekaran M, Rasheed MH, Suresh RV, Sivaprakash S (2006) Evaluation of bone mineral density in thyrotoxicosis. Singapore Med J 47:947-950.

[144] Varga F, Rumpler M, Luegmayr E, Fratzl-Zelman N, Glantschnig H, Klaushofer K (1997) Triiodothyronine, a regulator of osteoblastic differentiation: depression of histone H4, attenuation of c-fos/c-jun, and induction of osteocalcin expression. Calcif Tissue Int 61:404-411

[145] Vadiveloo T, Donnan PT, Cochrane L, Leese GP (2011) The Thyroid Epidemiology, Audit, and Research Study (TEARS): morbidity in patients with endogenous subclinical hyperthyroidism. J Clin Endocrinol Metab 96:1344-51.

[146] Vestergaard P, Mosekilde L (2002) Fractures in patients with hyperthyroidism and hypothyroidism: a nationwide follow-up study in 16,249 patients. Thyroid 12: 411-419.

[147] Vestergaard P, Rejnmark L, Mosekilde L (2005) Influence of hyper- and hypothyroidism, and the effects of treatment with anti-thyroid drugs and levothyroxine on fracture risk. Calcif Tissue Int 77: 139-144.

[148] Vestergaard P, Rejnmark L, Weeke J, Mosekilde L (2000) Fracture risk in patients treated for hyperthyroidism. Thyroid 10:341-348.

[149] Wagner B, Begic-Karup S, Raber W, Schneider B, Waldhäusl W, Vierhapper H (1999) Prevalence of primary hyperparathyroidism in 13387 patients with thyroid diseases, newly diagnosed by screening of serum calcium. Exp Clin Endocrinol Diabetes. 107:457-61.

[150] Wang, L. et al. (2007) Thyroid hormone interacts with the Wnt/betacatenin signaling pathway in the terminal differentiation of growth plate chondrocytes. J. Bone Miner. Res. 22, 1988-1995

[151] Webb P (2010). Thyroid hormone receptor and lipid regulation. Curr Opin Investig Drugs 11(10), 1135-1142.

[152] Weinberger C, Thompson CC, Ong, ES, Lebo R, Gruol DJ, \& Evans RM (1986) The cerb-A gene encodes a thyroid hormone receptor. Nature 324: 641-646.

[153] Weiss RE, Refetoff S (2000) Resistance to thyroid hormone. Rev Endocr Metab Disord 1:97-108.

[154] Wejda B, Hintze G, Katschinski B, Olbricht T, Benker G (1995) Hip fractures and the thyroid: A case study. J Intern Med 237:241-247 
[155] Williams GR, Bland R, and Sheppard MC (1994) Characterization of thyroid hormone (T3) receptors in three osteosarcoma cell lines of distinct osteoblast phenotype: interactions among T3, vitamin D3, and retinoid signaling. Endocrinology 135: 23752385, 1994.

[156] Williams GR (2000) Cloning and characterization of two novel thyroid hormone receptor beta isoforms. Mol Cell Biol 20:8329-8342

[157] Wilkis L (1941) Epiphysial dysgenesis associated with hypothyroidism. Am J Dis Child. 61:13-34.

[158] Wikstrom L, Johansson C, Salto C, Barlow C, Campos Barros A, Baas F, Forrest D, Thoren P, Vennstrom B (1998) Abnormal heart rate and body temperature in mice lacking thyroid hormone receptor alpha 1. EMBO J 17:455-461.

[159] Yamoah K, Brebene A, Baliram R, et al (2008) High-mobility group box proteins modulate tumor necrosis factor-alpha expression in osteoclastogenesis via a novel deoxyribonucleic acid sequence. Mol Endocrinol 22:1141-1153. 